\title{
Preface to the
}

\section{American Edition}

This American edition modifies somewhat the Italian edition of 1980 as well as the Spanish translation of 1989 . In particular, I eliminated sections at odds with today's critical literature on Vienna around the turn of the last century. I have little interest in the amorphous "strudel" made of waltzes, decadence, a carefree apocalypse, and theatrical destinies that in the course of the last twenty years has come to be glorified as "Grand Vienna."

The last essay of the American edition, "Profane Attention," on Robert Musil, is not in either the Italian edition or the Spanish translation. It first appeared in 1979 in Metaphorein, the journal edited by my unforgettable friend, the great Italian Germanist Ferruccio Masini, to whose memory this new edition of my book is dedicated.

Attentive readers should recognize that this book is not simply a collection of scattered essays. Its diverse figures and various tempos form what I would rather call a Liederzyklus, a song cycle. This quality differentiates it from my subsequent books, Icone della Legge (1985), which will appear in English translation soon, and L'Angelo necessario (1986), already available as The Necessary Angel. 